\section{Analysis of E-coded food additives in delicatessen product labels within the status of Halal food}

\section{ABSTRACT}

The increase in the world population, technological developments and the increase in the demand for food have increased the use of food additives due to the increasing demand for ready and long-lasting foods. The sources of food additives and the way they are obtained are questioned by people primarily for religious reasons. Muslim societies do not consume certain foods and additives added to them due to their religious beliefs. The aim of this study is to identify those suspected to be halal among E-coded additives on meat product labels. Within the scope of the study the label information of the meat products on sale in 5 different markets in the city center of Şanliurfa were examined. Food labels of 122 products from different brands were examined. We identified 12 different doubtful food additives on the labels of meat products, and 11 labels included 1 food additive defined as non-halal according to the standard. As the Muslim population is spreading all over the world and the need for Halal products is rapidly increasing, the Halal food industry is growing and the importance of proper Halal certification of food products is increasing. It is necessary to clarify the Halal status of food additives in order to meet Halal requirements.

Keywords: Food additives, non-halal, meat products

\section{T}

\section{NTRODUCTION}

The increasing need for food due to the rapid increase of the world population, the development of technology, and the increase in the tendency of people to ready and long-lasting foods with the change of food demand have increased the use of food additives. Food additives are used for different purposes in foods (Table 1). Food additives are defined by the Codex Alimentarius Commission as follows: "which is not used as food alone, whether it has nutritive value or not, is added to foods for technological purposes in manufacturing, processing, preparation, application, packaging, transportation, storage, or which become a direct or indirect component of foods or the characteristics of foods (Codex Stan, 2020). There are different opinions in the scientific community about the health effects of food additives. According to the opinion that advocates Food Additives, it is that food additives go through a very strict and serious approval process before they are put on the market and they are used far below the levels that can harm human health (Jain et al., 2015). The opposite view argues that scientific studies on the effects of using these substances together in all stages of food production are still insufficient (Eaton, 2016).

\section{How to cite this article}

Altun SK., Aydemir, ME. (2021). Analysis of E-coded food additives in delicatessen product labels within the status of Halal food. Journal of Advances in VetBio Science and Techniques, 6(1), 29-34. https://doi.org/10.31797/vetbio.869983
Research Article

Serap Kılıç Altun ${ }^{1 a}$

Mehmet Emin Aydemir ${ }^{1 b}$

${ }^{1}$ Department of Food Hygiene and

Technology, Faculty of Veterinary Medicine, Harran University, Şanlıurfa, Turkey

ORCID-

${ }^{\mathrm{a}} \underline{0000-0002-4203-2508}$

b0000-0002-5849-1741

Correspondence

Mehmet Emin Aydemir

aydemiremin23@harran.edu.tr

Article info

Submission: 28-01-2021

Accepted: 23-03-2021

Online First: 07-04-2021

e-ISSN: 2548-1150

doi prefix: $10.31797 /$ vetbio

- http://dergipark.org.tr/vetbio

This work is licensed under a Creative Commons Attribution 4.0 International License (c) $\underset{\mathrm{EY}}{(7)}$ 
Table 1. Classification of food additives according to their purpose of usage (Özgen \& Hazarhun, 2019; Ekşi, 2014)

\begin{tabular}{|c|c|}
\hline Function & Purpose of usage \\
\hline $\begin{array}{l}\text { Acids and Acidity } \\
\text { Regulators }\end{array}$ & $\begin{array}{l}\text { Regulates acid and base balance } \\
\text { in foods }\end{array}$ \\
\hline Antioxidants & $\begin{array}{l}\text { Provides the extension of the } \\
\text { shelf life of foods }\end{array}$ \\
\hline Colorants & Provides food coloring \\
\hline Stabilizers & Provides density to foods \\
\hline Emulsifiers & $\begin{array}{l}\text { Allows mixing of two or more } \\
\text { phases that do not interfere with } \\
\text { each other }\end{array}$ \\
\hline Bulking Agents & $\begin{array}{l}\text { Increases the volume of foods } \\
\text { without increasing their calorie } \\
\text { value }\end{array}$ \\
\hline Foaming Agents & $\begin{array}{l}\text { Provides the formation or } \\
\text { homogeneous distribution of the } \\
\text { gas phase in liquids and solids }\end{array}$ \\
\hline Gelling Agents & $\begin{array}{l}\text { Provides the food to have a gel- } \\
\text { like structure }\end{array}$ \\
\hline Propellant Gases & $\begin{array}{l}\text { Makes it easier for food to come } \\
\text { out of its packaging }\end{array}$ \\
\hline Embossing Agents & Makes dough rise \\
\hline Preservatives & $\begin{array}{l}\text { Prevents the rotting of foods due } \\
\text { to microorganisms and extends } \\
\text { the shelf life }\end{array}$ \\
\hline Thickening Agents & $\begin{array}{l}\text { Increases the resistance of food to } \\
\text { fluidity }\end{array}$ \\
\hline Antifoams & Prevents food from foaming \\
\hline Flavor Enhancers & $\begin{array}{l}\text { Increases the taste or odor in } \\
\text { foods }\end{array}$ \\
\hline Glazing Agents & $\begin{array}{l}\text { Creates a shiny and protective } \\
\text { coating on the outer surface of } \\
\text { food }\end{array}$ \\
\hline Flavors & $\begin{array}{l}\text { Gives food a particular taste or } \\
\text { smell }\end{array}$ \\
\hline Humectants & Prevents food from drying out \\
\hline Sweeteners & Keeps the food energy low \\
\hline Anti-Caking Agents & $\begin{array}{l}\text { Prevents particles in food from } \\
\text { sticking to each other }\end{array}$ \\
\hline Tracer Gases & $\begin{array}{l}\text { Prevents food from being exposed } \\
\text { to the atmosphere }\end{array}$ \\
\hline $\begin{array}{l}\text { Flour Treatment } \\
\text { Agents }\end{array}$ & Improves flours' color \\
\hline
\end{tabular}

In order to standardize food additives, Ecodes, the first letter of the word Europe, have been given to the European Union by countries (Verbruggen, 2002).

The sources of food additives and the way they are obtained are questioned by people primarily for religious reasons. Muslim societies do not consume certain foods and additives added to them due to their religious beliefs. The uncertainty of which raw materials the food is produced from poses an important problem for consumers with religious sensitivity (Batu \& Regenstein, 2014). Especially the food additives should be checked religiously (Küçüköner, 2011).

The word halal is an Arabic origin word which means 'not contrary to the rules of religion, not prohibited in terms of religion' in the dictionary of the Turkish Language Association (TDK, 2020). Halal food refers to foods that are allowed to be eaten and drunk in Islamic Jurisprudence. The purpose of these restrictions on nutrition brought by the Quran to Muslims is to protect people's health. Consumption of food products that will endanger people's health is considered as haram according to Islamic religious rules (Karaman, 2012). The Halal and Haram are understandable and in among two of them are doubtful (Jahangir et al., 2016). Food additives are considered halal as long as they do not affect human health negatively, as long as they are herbal or if they are obtained from animals that are halal to be eaten in accordance with religious rules, according to Islamic methods. It must not have been obtained from the prohibited substances mentioned in the Quran and Hadith-i Sharifs and must not be genetically modified (Özgen \& Hazarhun, 2019; Çelen, 2008). The sources of food additives and the way they are obtained are questioned by people primarily for religious reasons. Muslim societies do not consume certain foods and additives added to them due to their religious beliefs. The uncertainty of which raw materials the food is produced from poses an important problem for consumers with religious sensitivity. Especially the food additives should be checked religiously. The word halal on food additives and foods has become a reason of preference for non-Muslim consumers in terms of hygiene and health (Baharuddin et al., 2015). For all these reasons, it is very important to have Halal certification, to inspect food companies by an impartial institution, to confirm that they are produced in accordance with halal standards and to provide a certificate 
of halal (OIC/SMIIC, 2020). The official international standards body Standards and Metrology Institute for the Islamic Countries (SMIIC), the affiliated institution to the Organization of Islamic Cooperation (OIC), have released General Requirements for Food Additives and Other Added Chemicals to Halal Food (OIC/SMIIC, 2020). The halal status of some food additives was determined in this published general requirement standard. The aim of this study is to identify those suspected to be halal among E-coded additives on meat product labels.

\section{MATERIALS and METHODS}

This research is an observational descriptive study. In the study, the food group to be included in the research was determined, the labels of the products in the determined food group were examined, the E-codes on the food labels were listed and whether these E-coded additives are halal or not are classified. Within the scope of the study the label information of the meat products on sale in 5 different markets in the city center of Sanliurfa were examined. Food labels of 122 products from different brands were examined Figure1. The names of the brands whose labels are examined were not included in the study due to the ethical principles. In Figure 1, the number of products evaluated within the scope of the examined product groups are indicated.

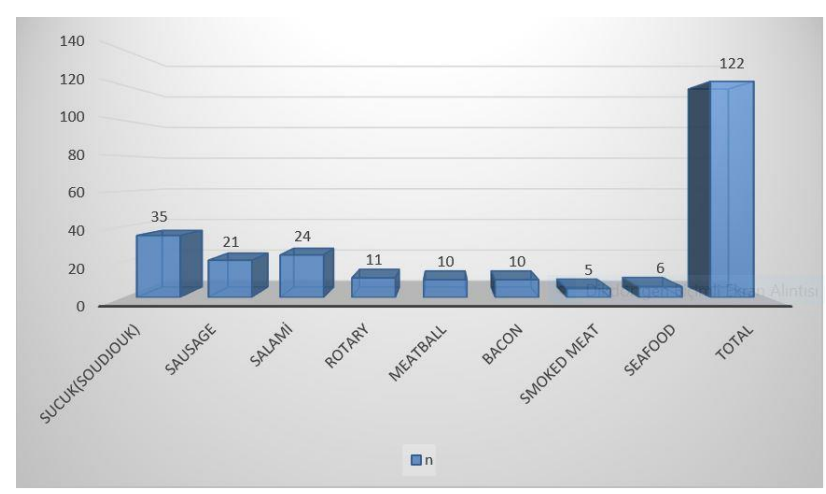

Figure 1. Distribution of samples by product groups

\section{RESULTS}

We identified 12 different doubtful food additives on the labels of meat products, and 11 labels included 1 food additive defined as nonhalal according to the standard. The distribution of E-codes, which are considered as doubtful and nonhalal in the labels examined in our research, according to the product groups is given in Table 2.

Table 2. Product groups doubtful and nonhalal in the labels examined

\begin{tabular}{|lccc|}
\hline Food group & $\begin{array}{c}\text { Number } \\
\text { of } \\
\text { products }\end{array}$ & $\begin{array}{c}\text { Number } \\
\text { of } \\
\text { doubtful } \\
\text { products }\end{array}$ & $\begin{array}{c}\text { Number } \\
\text { of non- } \\
\text { halal } \\
\text { products }\end{array}$ \\
\hline Beef meat products & 66 & 63 & 4 \\
\hline Chicken meat products & 30 & 30 & 4 \\
\hline Turkey meat products & 20 & 20 & 3 \\
\hline Seafood products & 6 & 5 & 0 \\
\hline Total & 122 & 118 & 11 \\
\hline
\end{tabular}

The distribution of E-codes in the labels examined in our research, according to the food additives is given in Table 3 .

Table 3. Halal status of the food additives

\begin{tabular}{|c|c|c|}
\hline E-Code & Number of products & Halal status \\
\hline E-120 & 11 & non-halal \\
\hline E-126 & 1 & not in standard \\
\hline E-160 & 5 & Doubtful \\
\hline E-207 & 1 & not in standart \\
\hline E-223 & 1 & not in standart \\
\hline E-250 & 85 & Doubtful \\
\hline E-262 & 23 & Doubtful \\
\hline E-300 & 59 & Doubtful \\
\hline E-301 & 33 & Doubtful \\
\hline E-316 & 11 & not in standart \\
\hline E-318 & 3 & not in standart \\
\hline E-325 & 23 & Doubtful \\
\hline E-330 & 1 & not in standart \\
\hline E-331 & 5 & Doubtful \\
\hline E-407 & 12 & Doubtful \\
\hline E-412 & 2 & Doubtful \\
\hline E-415 & 2 & Doubtful \\
\hline E-450 & 16 & not in standart \\
\hline E-451 & 8 & not in standart \\
\hline E-452 & 75 & not in standart \\
\hline E-500 & 2 & Doubtful \\
\hline E-575 & 4 & Doubtful \\
\hline E-1400 & 8 & not in standart \\
\hline E-4500 & 1 & not in standart \\
\hline
\end{tabular}




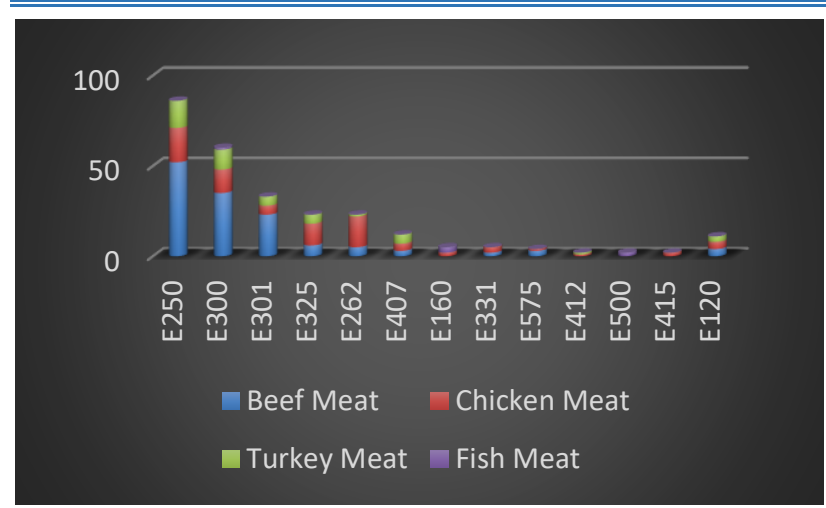

Figure 2. The distribution doubtful of E-codes according to the product groups.

The number of products with doubtful E-Codes is given in Table 4, Figure 2.

Table 4. Number of products with doubtful E-Codes

\begin{tabular}{|lccc|cc|}
\hline E-CODE & $\begin{array}{c}\text { Beef } \\
\text { Meat }\end{array}$ & $\begin{array}{c}\text { Chicken } \\
\text { Meat }\end{array}$ & $\begin{array}{c}\text { Turkey } \\
\text { Meat }\end{array}$ & $\begin{array}{c}\text { See } \\
\text { Food }\end{array}$ & $\begin{array}{c}\text { All } \\
\text { Products }\end{array}$ \\
\hline E-250 & 52 & 19 & 15 & 0 & 86 \\
\hline E-300 & 35 & 13 & 11 & 1 & 60 \\
\hline E-301 & 23 & 5 & 5 & 0 & 33 \\
\hline E-325 & 6 & 12 & 5 & 0 & 23 \\
\hline E-262 & 5 & 17 & 1 & 0 & 23 \\
\hline E-407 & 3 & 4 & 5 & 0 & 12 \\
\hline E-160 & 0 & 2 & 0 & 3 & 5 \\
\hline E-331 & 2 & 3 & 0 & 0 & 5 \\
\hline E-575 & 3 & 1 & 0 & 0 & 4 \\
\hline E-412 & 0 & 1 & 1 & 0 & 2 \\
\hline E-500 & 0 & 0 & 0 & 2 & 2 \\
\hline E-415 & 0 & 2 & 0 & 0 & 2 \\
\hline E-120 & 4 & 4 & 3 & 0 & 11 \\
\hline TOTAL & 133 & 83 & 46 & 6 & 268 \\
\hline
\end{tabular}

\section{DISCUSSION}

The most common sodium nitrite coded E-250 in our study $(\mathrm{n}: 85)$ is widely used as a preservative in meat products. Because it combines with the myoglobin in the meat and provides the formation of a bright pink-red color specific to the processed meats and the protection of this color. It also prevents the growth of Clostridium botulinum bacteria, which is very dangerous for human health. Besides these, it also has functions to prevent spoilage and stabilize the structure of the product. Unfortunately, many scientific studies have been carried out on its carcinogenic effect and its use has been prohibited in many countries (Ma et al., 2018). Ascorbic acid with the code E-300, which is the most common in beef meat, is used as an acidity regulator in meat products. But synthetically produced ascorbic acid is dangerous for human health. E160c (paprika extract) is the most common additive in seafood and it is obtained from the kernels and seeds of red peppers and can be mixed with gelatin; for this reason, its use as a food additive is prohibited in Australia. E-301, the sodium salt of ascorbic acid, also prevents nitrosamine formation in meat and is also used as an antioxidant, but its synthetic production is risky for public health. E-120 (Carmine) food additive, which is frequently used in meat and delicatessen products, is a controversial substance. Carmine derived from insects It is a food additive of animal origin since it is produced. It is free to use in Turkish food legislation and is considered non-halal according to the the Standards and Metrology Institute for Islamic Countries (SMIIC). This additive is stated on the halal Malaysia site to be non-halal only for those in the Hanafi fiqqah, and doubtful for others (OIC/SMIIC, 2020; Halal E-Codes, 2020) E-300, long name Ascorbic acid. This substance, which is found in many foods and beverages, is often labeled as vitamin C. Not the natural one, but the artificial one synthesized from glucose is considered suspicious and its health risks are discussed (Varvara et al., 2016). E-325 Sodium lactate used for its antimicrobial effect in foods is a risky food additive in young children with lactose intolerance, which is originally derived from milk but is considered suspicious because it may contain pig rennet (Aymerich et al., 2005). E-262 Sodium acetate or Sodium diacetate is widely used as acidity regulator in foods. However, in a study conducted in 2018, it was reported that rats showed lymphocytosis and even suppressed humoral parameters significantly, causing various pathological lesions (Abd-Elhakim et al., 2018). 
As the Muslim population is spreading all over the world and the need for Halal products is rapidly increasing, the Halal food industry is growing and the importance of proper Halal certification of food products is increasing. It is necessary to clarify the Halal status of food additives in order to meet Halal requirements. There is great demand for clarification of questionable situations in food production, which can assist Muslim consumers with their religious obligation to ensure that food is Halal. Using raw materials and additives from Halal approved sources and using the appropriate technique will ensure the product to be Halal and create trust among consumers. The use of food additives, which may adversely affect human health as a result of the analysis of international food organizations and reliable laboratories, should be prohibited by the governments. This should be done for the purpose of protecting public health and not just for religious reasons.

\section{CONCLUSION}

Food additive lists of various institutions and organizations that issue halal certification around the world should be uniform. For this reason, food scientists and religious authorities should do more scientific work on the standardization of halal additives. Using systems such as listing and coding companies with halal food certification by the certification institutions whether the manufacturers have this certificate should be made clearly visible to the consumers. Because halal food is necessary not only for Muslims but also for all humanity in terms of health.

\section{ACKNOWLEDGMENT}

This study was presented as oral presentation at the $6^{\text {th }}$ World Halal Summit on December 2123, 2020 in İstanbul, Turkey.

Ethical approval: In this study, neither humans/animals nor any non-ethical objects were not used for experimental or other scientific purposes.

Conflict of interest: The authors declare that there is no conflict of interest for this study.

\section{REFERENCES}

Abd-Elhakim, Y. M., Hashem, M. M., Anwar, A., ElMetwally, A. E., Abo-El-Sooud, K., Moustafa, G. G., \& Ali, H. A. (2018). Effects of the food additives sodium acid pyrophosphate, sodium acetate, and citric acid on hemato-immunological pathological biomarkers in rats: Relation to PPAR- $\alpha$, PPAR- $\gamma$ and tnf $\alpha$ signaling pathway. Environmental toxicology and pharmacology, 62, 98-106. doi:10.1016/j.etap.2018. $\underline{07.002}$

Aymerich, T., Jofre, A., Garriga, M., \& Hugas, M. (2005). Inhibition of Listeria monocytogenes and Salmonella by natural antimicrobials and high hydrostatic pressure in sliced cooked ham. Journal of Food Protection, 68(1), 173-177. doi:10.4315/0362028X-68.1.173

Baharuddin, K., Kassim, N.A., Nordin, S.K., \& Buyong, S.Z. (2015). Understanding the halal concept and the importance of information on halal food business needed by potential Malaysian entrepreneurs. International Journal of Academic Research In Business And Social Sciences, 5(2), 170181. doi:10.6007/IJARBSS/v5-i2/1476

Batu, A., \& Regenstein, J. M. (2014). Halal food certification challenges and their implications for muslım societies worldwide. Electronic Turkish Studies, 9(11), 111-130.

Codex Stan. (2020, December 07) General standards for food additives. https://www.bsmi.gov.tw/wSite/ public/Data/f1295594710650.pdf

Çelen, M. (2008). Gıda katk1 maddelerinin helal olma şartları. 1.uluslararası helal gıda konferansı bildiri kitabl, 60-71.

Ekşi, A. (2014). Başlıca gıda katkıları ve kullanılma amaçları. M. Tayfur (Ed.) A'dan Z'ye gıda katkı maddeleri içinde (ss.52-75). Ankara: Detay yayıncilik

Eaton, B. (2020, December 04) Food additives: Definition, history and debate. https://bruceeatonphd.wordpress.com/2016/04/08/foo d-additives-definition-history-and-debate/

Halal E-Codes, (2020, December 05). Malaysian Halal Consultation and Training. http://halalmalaysia.net/ HALAL E-CODES.php

Jahangir, M., Mehmood, Z., Bashir, Q., Mehboob, F., \& Ali, K. (2016). Halal status of ingredients after physicochemical alteration (Istihalah). Trends in Food Science \& Technology, 47, 78-81. doi:10.1016/j.tifs. 2015.10.011

Jain, A., \& Mathur, P. (2015). Evaluating hazards posed by additives in food a review of studies adopting a risk assessment approach. Current Research in Nutrition and Food Science, 3(3), 243-255. doi:10. 12944/CRNFSJ.3.3.08 
Karaman, A. (2012). G1da Ürünlerinde Helal ve Haramı Belirleme Yöntemi. C.Ü. Ilahiyat Fakültesi Dergisi, 16(1), 453-478.

Küçüköner, E. (2011). Helal gıda serti-fikasyonunda gida katk1 maddelerinin yeri. 1.Ulusal Helal ve Sağlıklı Gıda Kongresi Bildiriler Kitabı, 12- 17.

Ma, L., Hu, L., Feng, X., \& Wang, S. (2018). Nitrate and nitrite in health and disease. Aging and Disease, 9(5), 938. doi: 10.14336 / AD.2017.1207

OIC/SMIIC. (2020). General requirements for food additives and other added chemicals to halal food 24:2020.

Özgen, I., \& Hazarhun, E. (2019). G1da etiketlerindeki E-kodlu katk1 maddelerinin helal g1da kapsaminda incelenmesi. Balikesir University Journal of Social Sciences Institute, 22(41). doi:10.31795/baunsobed. 580561

TDK, (2020, December 05) Halal word. https://www.tdk.gov.tr/

Varvara, M., Bozzo, G., Celano, G., Disanto, C., Pagliarone, C. N., \& Celano, G. V. (2016). The use of ascorbic acid as a food additive: technical-legal issues. Italian Journal of Food Safety, 5(1). 10.4081 / ijfs.2016.4313

Verbruggen, R. (2002). Avrupa Birliği'ndeki g1da katk1 maddeleri. Gida Bilimi ve Teknolojisi, New York; Marcel Dekker, 109-198. 